\title{
Pengaruh Kemampuan Teknik Personal, Keterlibatan Pemakai, Pelatihan Dan Pendidikan Pada Kinerja Sistem Informasi Akuntansi
}

\author{
I Gusti Ngurah Putu Ardiwinata ${ }^{1}$ \\ I Ketut Sujana ${ }^{2}$
}

\author{
${ }^{1,2}$ Fakultas Ekonomi dan Bisnis Universitas Udayana (Unud), Bali, Indonesia \\ e-mail: ardiwinata.wawah@yahoo.com
}

\begin{abstract}
ABSTRAK
Sistem informasi merupakan dasar bagi jalannya bisnis saat ini. Organisasi membutuhkan system informasi untuk mempertahankan kemampuan bersaing. Tujuan penelitian ini adalah mengetahui dan mendapatkan bukti empiris mengenai pengaruh kemampuan teknik personal, keterlibatan pemakai, pelatihan dan pendidikan pada kinerja system informasi akuntansi. Populasi penelitian ini adalah seluruh pegawai LPD yang berada di Kota Denpasar. Teknik pengambilan sampel yang digunakan adalah purposive sampling, sehingga diperoleh jumlah sampel responden sebanyak 99 orang pegawai. Responden dalam penelitian ini adalah ketua, tata usaha, kasir/admin dan pegawai di LPD yang sudah mempergunakan SIA berbasis komputer secara langsung. Teknik analisis yang digunakan adalah analisis regresi linier berganda. Hasil penelitian ini menunjukkan bahwa kemampuan teknik personal, keterlibatan pemakai, serta pelatihan dan pendidikan berpengaruh positif dan signifikan terhadap Kinerja system informasi akuntansi pada LPD di Kota Denpasar.
\end{abstract}

Kata Kunci: Kemampuan teknik personal, keterlibatan pemakai, pelatihan dan pendidikan, kinerja SIA

\begin{abstract}
Information systems are the basis for the running of business today. Organizations need information systems to maintain competitiveness. The purpose of this study was to find out and obtain empirical evidence regarding the influence of personal technical skills, user involvement, training and education on the performance of accounting information systems. The population of this research is all LPD employees in the city of Denpasar. The sampling technique used was purposive sampling, so that the number of respondents obtained as many as 99 employees. Respondents in this study were the chairman, administration, cashier / admin and employees in the LPD who had used computer-based SIA directly. The analysis technique used is multiple linear regression analysis. The results of this study indicate that personal technical abilities, user involvement, and training and education have a positive and significant effect on the performance of accounting information systems in LPD in Denpasar City.

Keywords: Personal technical skills, user involvement, training and education, SIA performance
\end{abstract}

\section{PENDAHULUAN}

Perkembangan teknologi informasi berlangsung sangat cepat dan pesat pada peningkatan penggunaan teknologi komputer merupakan dampak dari 
perkembangan teknologi informasi. Sebelum terjadi peningkatan kemajuan teknologi informasi, sebagian besar waktu yang digunakan oleh individu di dalam perusahaan dan penggunaan sistem informasi dilakukan secara manual. Setelah terjadi peningkatan perkembangan teknologi informasi, banyak perusahaan beralih pada pendayagunaan sistem informasi yang berbasis komputer karena akan memudahkan dan mempercepat manajemen untuk mengolah informasi yang akan di input. Xu and Dandong (2003) menyatakan bahwa kualitas informasi menjadi penting bagi keberhasilan sistem informasi akuntansi ditengah teknologi informasi yang berkembang saat ini

Sistem informasi merupakan dasar bagi jalannya bisnis saat ini karena organisasi membutuhkan sistem informasi untuk mempertahankan kemampuan bersaing. Menurut Laudon (2008) sistem informasi secara teknis dapat didefenisikan sabagai sekumpulan komponen yang saling berhubungan untuk mengumpulkan, memproses, menyimpan, dan mendistribusikan informasi yang berguna sebagai alat pengambilan keputusan dan pengawasan dalam suatu organisasi. Perusahaan atau organisasi dapat meningkatkan kinerja melalui penggunaan sarana teknologi informasi (Alanita dan Suaryana, 2014). Peningkatan kinerja perusahaan dan bisnis melalui penggunaan teknologi dibutuhkan suatu sistem yang mampu menangkap, menciptakan, dan mengelola informasi dari dalam maupun dari luar. Informasi yang dihasilkan tersebut merupakan output baru sistem informasi. Sistem informasi sangat penting dalam lembaga guna menunjang kelancaran kinerja lembaga, termasuk pada Lembaga Perkreditan Desa (LPD). LPD di Kota Denpasar telah menggunakan sistem 
informasi akuntansi berbasis computer dengan tujuan dapat menghasilkan kinerja yang maksimal.

Salah satu hal yang utama dari sebuah sistem adalah data yang diolah dapat menghasilkan suatu informasi yang dibutuhkan. Al-eqab and Adel (2013) menyatakan, SIA penting bagi semua organisasi ataupun perusahaan untuk meningkatkan efisiensi organisasi dan mendukung daya saing perusahaan melalui penyediaan informasi keuangan dan akuntansi bagi manajemen. Sehingga fungsi sebuah sistem sebagaisistem informasi menjadi hal yang sangat diutamakan bagi setiap perusahaan. SIA dapat membantu manajemen dalam pengambilan keputusan serta melihat pengaruh terhadap lingkungan bisnis dalam skala global (Beke, 2010). Oleh karena itu sistem informasi akuntansi (SIA) harus dirancang sesuai dengan kepentingan atau kebutuhan perusahaan sehingga dapat menghasilkan informasi yang berkualitas dan akurat serta dapat dipertanggung jawabkan. Sistem informasi yang baik tidak hanya digunakan untuk menyimpan data secara elektronik tetapi juga harus mampu mendukung proses analisis yang dilakukan oleh manajemen (Edi dan Wahyuningrum, 2017). Baik buruknya kinerja dari sebuah Sistem Informasi Akuntansi dapat dilihat melalui kepuasan pemakai Sistem Informasi Akuntansi dan pemakaian Sistem Informasi Akuntansi itu sendiri (Swandewi dkk., 2017). Pengukuran keberhasilan penerapan sistem informasi sangat diperlukan bagi manajemen untuk mengetahui apakah investasi yang telah dikeluarkan memberi nilai tambah bagi perusahaan. Menurut Wibowo (2007) menyatakan kinerja merupakan suatu proses tentang bagaimana pekerjaan berlangsung untuk mencapai hasil kerja. 
Kinerja Sistem Informasi Akuntansi dapat dikatakan baik jika informasi yang diterima memenuhi harapan pemakai oleh faktor-faktor yang meliputi kemampuan teknik personal, kecanggihan teknologi informasi dan partisipasi pengguna. Akan tetapi pada kenyataan yang ada dalam perusahaan, terdapat beberapa permasalahan, yaitu pertama, sering terjadi human error seperti terjadi kesalahan staf dalam menyalin dan mengisi data. Faktor-faktor lain yang mempengaruhi kinerja SIA meliputi dukungan manajemen puncak, formalisasi pengembangan sistem, kepuasan pemakai, keterlibatan pemakai SIA, serta program pelatihan dan pendidikan. Berdasarkan hal tersebut maka suatu organisasi perlu memerhatikan faktor-faktor yang memengaruhi kinerja sistem informasi akuntansi.

Penelitian menganai kinerja sistem informsi akuntansi telah banyak dilakukan diantaranya dalam penelitian Septi (2017) "Pengaruh Kecanggihan Teknologi Informasi, Partisipasi Pengguna, dan Kemampuan Pengguna Terhadap Kinerja Sistem Informasi Akuntansi Pada PT PLN (Persero) Area Bali Utara (Kantor Pusat)" mendapatkan hasil bahwa kecanggihan teknologi informasi, partisipasi pengguna, dan kemampuan pengguna berpengaruh positif dan signifikan terhadap kinerja sistem informasi akuntansi. Penelitian yang dilakukan oleh Tjhai (2002) "Faktor-Faktor yang Mempengaruhi Kinerja Sistem Informasi Akuntansi" memperoleh hasil pengujian proses pengembangan sistem, kemampuan teknik personal, dukungan manajemen puncak, ukuran organisasi memiliki hubungan positif dengan kinerja SIA. 
Penelitian mengenai kinerja sistem informasi akuntansi telah banyak dilakukan, tetapi masih terdapat ketidak konsistenanan pada hasil penelitian yang telah dilakukan. Penelitian yang dilakukan Damana dan Suardikha (2016) menyimpulkan keterlibatan pemakai, pelatihan, dan keahlian pemakai berpengaruh positif terhadap kinerja system informasi akuntansi. Komara (2006) menemukan ada pengaruh positif dan signifikan antara variabel keterlibatan pemakai dalam pengembangaan SIA dengan kinerja SIA namun Almilia dan Briliantien (2007) tidak menemukan adanya hubungan antar variabel tersebut. Demikian pula pada penelitian Ayu (2012) menemukan adanya hubungan yang signifikan antara program pendidikan dan pelatihan pemakai dengan kinerja SIA namun pada penelitian Utama (2014) tidak menemukan adanya hubungan antar variabel tersebut.

Kemampuan teknik personal dalam pengunaan informasi pada suatu perusahaan, dapat dilihat dari kemudahan pemakai dalam mengidentifikasi data, mengakses data dan menginterpretasikan data tersebut. Kemampuan teknik personal akuntansi yang baik akan mendorong pemakai untuk menggunakan sistem informasi akuntansi sehingga kinerja sistem informasi akan lebih tinggi. Kemampuan teknik personal merupakan suatu hal yang tidak terlepas dari penerapan teknologi, selain itu keberadaan manusia sangat berperan penting dalam penerapan teknologi (Putri dan Dharmadiaksa, 2015). Menurut Robbins (2008) kemampuan pemakai dapat dilihat dari bagaimana pemakai sistem menjalakan sistem informasi yang ada. Selain itu, kemampuan teknik personal 
dalam mengoperasikan sistem informasi sangat dibutuhkan, hal ini penting dalam hal mengoperasikan sistem agar dapat beroperasi secara maksimal.

Penelitian yang dilakukan Adventri (2008), Wirayanti dkk., (2015) membuktikan bahwa kemampuan teknik personal akuntansi barpengaruh terhadap kinerja sistem informasi akuntansi. Untuk kemampuan personal sistem informasi berarti seberapa baik kemampuan yang dimiliki oleh user artinya semakin baik kapabilitasnya akan semakin meningkatkan kinerja sistem informasi akuntansi. Suatu sistem informasi harus mampu memberikan kontribusi yang maksimal dalam memecahkan masalah organisasi. Sistem informasi yang baik akan meningkatkan efisiensi dan proses fisik (adanya pengurangan biaya produksi), meningkatkan akurasi dan currency catatan yang berkaitan dengan berbagai macam entitas, memperbaiki kualitas produk dan jasa yang dihasilkan serta meningkatkan kualitas pengendalian dan perencanaan.

Salah satu faktor yang mempengaruhi kinerja SIA adalah keterlibatan pemakai. Menurut Damana dan Suardikha (2016) keterlibatan pemakai adalah keterlibatan mental dan emosional orang-orang dalam sistuasi kelompok yang mendorong mereka untuk memberikan kontribusi kepada tujuan kelompok yang mendorong mereka untuk memberikan kontribusi kepada tujuan kelompok. Rouibah et al., (2009) menjelaskan bahwa saat organisasi atau perusahaan percaya pada pengguna sistemnya, maka penggunaan sistem itu sendiri akan lebih meningkat. Hal serupa juga ditanyakan oleh Alanita dan Suaryana (2014) partisipasi pengguna dalam pengembangan sistem informasi akuntansi adalah faktor efektif yang berpengaruh terhadap kinerja sistem informasi akuntansi. 
Pelatihan merupakan sesuatu yang terpenting guna memberikan latar belakang yang bertujuan mendekatkan pemakai dengan penggunaan teknik komputer secara umum sebagai proses penggunaan sistem yang spesifik. Nithyanandam et al., (2006) menyatakan bahwa program pendidikan dibutuhkan untuk memaksimalkan kinerja para pemakainya. Menurut Tian-Hui (2009) pelatihan dan pendidikan pemakai bertujuan untuk meningkatkan kesadaran akan informasi dan keterampilan dalam pengambilan keputusan.

Fungsi utama dari sistem informasi akuntansi adalah memproduksi informasi berdasarkan data yang merupakan hasil dari transaksi keuangan (Marija et al., 2011). Sistem informasi akuntansi memiliki peranan yang sangat potensial dalam pengembangan dan penyediaan informasi sebagai pengendalian manajemen dan membantu dalam pengambilan sebuah keputusan. Lembaga keuangan mulai memanfaatkan Sistem Informasi Akuntansi berbasis komputer, salah satunya adalah Lembaga Perkreditan Desa yang merupakan badan usaha keuangan milik desa pakraman dimana lembaga ini melakukan kegiatan operasionalnya di lingkungan desa untuk melayani masyarakat desa setempat.

Menurut Utama (2014) menilai kinerja suatu LPD diperlukan laporan keuangan yang baik dan lengkap, oleh karena itu diperlukan juga sebuah sistem informasi akuntansi yang didukung oleh teknologi informasi yang terkomputerisasi. Ini berarti jika menginginkan kinerja dari sebuah LPD meningkat maka haruslah didukung oleh kinerja sistem informasi yang baik. Agar sebuah LPD dapat menghasilkan kinerja yang baik, sebaiknya sistem yang digunakan di dukung oleh sistem informasi yang terkomputerisasi. 
Beberapa fenomena yang terjadi di LPD kota denpasar menurut salah satu narasumber di Lembaga Pemberdayaan Lembaga Perkreditan Desa (LPLPD) tersebut bahwa masih adanya beberapa LPD dikota denpasar yang belum secara optimal menggunakan sistem informasi akuntansi secara integritas dan komputerisasi, maka LPD tersebut tidak bisa mengimbangi bersaing dengan LPD yang lainnya karena dari input,output dan informasi yang dihasilkan kurang efisien. LPD yang sudah menggunakan SIA secara integritas dan kompetentif dilihat dari perkembangan asset LPD yang meningkat setiap tahunnya karena didukung oleh pemanfaatan teknologi informasi tersebut yang secara optimal sehingga LPD tersebut mampu bersaing dan bisa dikatakan cukup sehat.

Penggunaan sistem informasi akuntansi akan berjalan optimal apabila diimbangi dengan kemampuan teknik penggunanya, sistem informasi akuntansi akan berhasil diterapkan dengan optimal di perusahaan apabila penggunanya memiliki kemampuan teknik yang baik sehingga sistem informasi akuntansi berjalan sesuai fungsinya (Gunawan dan Indra, 2017). Topik penelitian ini mengacu pada teori Technology Acceptance Model (TAM). Teori TAM merupakan suatu teori terkait mengenai sistem informasi yang memuat model mengenai sikap individu untuk menerima dan menggunakan teknologi. Teori Technology Acceptance Model (TAM) menjelaskan bahwa terdapat dua faktor yang memengaruhi perilaku personal untuk menerima dan menggunakan teknologi. Perluasan konsep TAM diharapkan akan membantu memprediksi sikap dan penerimaan seseorang terhadap teknologi dan dapat memberikan informasi mendasar yang diperlukan mengenai faktor-faktor yang menjadi pendorong sikap 
individu tersebut (Rose and Gerard, 2006). Berdasarkan teori ini menggambarkan bahwa kemampuan perlu untuk dimiliki oleh pengguna SIA karena semakin baik kemampuan teknik pemakai maka penggunaan SIA akan terasa mudah sehingga dapat mendorong pemakai dalam penggunaan SIA dengan lebih optimal dan pada akhirnya dapat meningkatkan kinerja SIA. Semakin baiknya kemampuan teknik dari pemakai dapat meningkatkan kepuasan pemakai dalam penggunaan SIA sehingga dapat mendorong pemakai untuk terus menggunakannya dalam membantu menyelesaikan pekerjaannya.

Kemampuan teknik personal pemakai sistem informasi sangat bermanfaat dan berperan penting dalam pengembangan sistem informasi untuk dapat menghasilkan informasi guna menciptakan laporan perencanaan yang akurat. Selain itu suatu sistem informasi akan lebih bermanfaat dalam membantu aktivitas apabila personel yang menggunakan sistem informasi tersebut, memiliki kemampuan untuk mengoperasikan sistem informasi tersebut (Fani dkk., 2015). Oleh karena itu, setiap karyawan harus dapat menguasai penggunaan sistem berbasis komputer agar dapat memproses sejumlah transaksi dengan cepat dan terintegrasi, dapat menyimpan data dan mengambil data dalam jumlah yang besar, dapat mengurangi kesalahan matematik, menghasilkan laporan tepat waktu dalam berbagai bentuk, serta dapat menjadi alat bantu keputusan (Suartika dan Sari, 2017).

Semakin tinggi kemampuan teknik personal Sistem Informasi Akuntansi dikarenakan adanya hubungan yang positif antara kemampuan teknik personal sistem informasi akuntansi dengan kinerja sistem informasi akuntansi (Almilia 
and Briliantien, 2007). Pemakai atau pengguna merupakan suatu hal yang tidak terlepas penerapan teknologi, selain itu keberadaan manusia sangat berperan penting dalam penerapan teknologi. Kemampuan teknik personal sistem informasi merupakan pengaruh utama dari perekrutan pegawai dan perancangan sistem informasi akuntansi.

Para peneliti sebelumnya seperti Adventri (2008), Wirayanti dkk. (2015) memperoleh kesimpulan bahwa kemampuan teknik personal akuntansi barpengaruh positif signifikan terhadap kinerja sistem informasi akuntansi. Berdasarkan hal tersebut maka hipotesis yang dapat disimpulkan adalah:

$\mathrm{H}_{1}$ : Kemampuan teknik personal berpengaruh positif pada kinerja sistem informasi akuntansi.

Keterlibatan pengguna merupakan keterlibatan dalam proses pengembangan sistem oleh anggota organisasi atau anggota dari kelompok pengguna target. Topik penelitian ini mengacu pada teori Technology Acceptance Model (TAM). Teori TAM merupakan suatu teori terkait mengenai sistem informasi yang memuat model mengenai sikap individu untuk menerima dan menggunakan teknologi. Teori Technology Acceptance Model (TAM) menjelaskan bahwa terdapat dua faktor yang memengaruhi perilaku personal untuk menerima dan menggunakan teknologi. Dua faktor tersebut adalah kemanfaatan dan kemudahan dalam penggunaan teknologi (Surendran, 2012). Berdasarkan teori ini menggambarkan bahwa keterlibatan pengguna dalam menggunakan SIA diperusahaan sangat diperlukan karena SIA memberikan manfaat dan kemudahan dalam proses penyusunan laporan sehingga dengan adanya tingkat keterlibatan pemakai SIA yang tinggi maka pengunaan SIA akan semakin efektif dan kinerja 
SIA yang dihasilkan akan semakin meningkat, sebaliknya semakin rendah keterlibatan personal pada penggunaan SIA maka efektivitas penggunaan SIA akan berkurang dan kinerja SIA yang dihasilkan akan semakin menurun.

Menurut Damana and Suardikha (2016) keterlibatan pemakai adalah keterlibatan mental dan emosional orang-orang dalam situasi kelompok yang mendorong mereka untuk memberikan kontribusi kepada tujuan kelompok. Hajiha and Azizi (2011) menyatakan pengembangan sistem informasi akuntansi adalah faktor efektif yang berpengaruh terhadap kinerja sistem informasi akuntansi.

Menurut Komara (2006) pengaruh keterlibatan pemakai dalam pengembangan sistem berpengaruh positif dan signifikan terhadap kinerja sistem informasi akuntansi. Begitu juga penelitian Damana dan Suardikha (2016) menyimpulkan keterlibatan pemakai berpengaruh positif terhadap kinerja SIA. Tjhai (2002) berpendapat bahwa keterlibatan pemakai yang semakin sering akan meningkatkan kinerja SIA dikarenakan adanya hubungan yang positif antara keterlibatan pemakai dalam proses pengembangan sistem informasi dalam kinerja SIA. Dengan demikian, hipotesis yang dapat dirumuskan sebagai berikut:

$\mathrm{H}_{2}$ : Keterlibatan pemakai dalam pengembangan sistem informasi berpengaruh positif terhadap kinerja sistem informasi akuntansi.

Sistem informasi akuntansi yang efektif juga harus diimbangi dengan program pelatihan dan pendidikan, hal ini perlu diadakan untuk karyawan dalam menjalankan sistem informasi akuntansi yang terkomputerisasi tersebut agar karyawan lebih terampil dalam menggunakan sistem yang ada, sehingga program pelatihan dan pendidikan tersebut akan memberikan keuntungan pada perusahaan 
dan pengguna sistem dalam menjalankan kegiatan operasional perusahaan. Topik penelitian ini mengacu pada teori Technology Acceptance Model (TAM). Teori TAM merupakan suatu teori terkait mengenai sistem informasi yang memuat model mengenai sikap individu untuk menerima dan menggunakan teknologi. Teori Technology Acceptance Model (TAM) menjelaskan bahwa terdapat dua faktor yang memengaruhi perilaku personal untuk menerima dan menggunakan teknologi. Dua faktor tersebut adalah kemanfaatan dan kemudahan dalam penggunaan teknologi (Surendran, 2012). Berdasarkan teori ini menggambarkan bahwa pendidikan dan pelatihan dalam menggunakan SIA diperusahaan sangat diperlukan karena dengan adanya pendidikan dan pelatihan maka pengguna SIA akan lebih memahami manfaat SIA dan mudah menggunakan aplikasi SIA tersebut. Jadi dengan adanya pendidikan dan pelatihan personal dapat meningkatkan pemahaman personal sehingga kemampuan teknik personal dapat meningkat. Kemampuan teknik personal yang meningkat dapat meningkatkan kepuasan personal dalam penggunaan SIA dan personal dapat menggunakan SIA dengan lebih baik sehingga kinerja SIA dapat meningkat.

Tjhai (2002) berpendapat bahwa kinerja SIA akan lebih tinggi apabila program pelatihan dan pendidikan merupakan alasan utama kurangnya pemanfaatan sistem informasi. Sebuah penelitian keutamaan dari sistem informasi yang dikemukakan oleh Soegiharto (2001) yaitu pendidikan pemakai sangat mempengaruhi kinerja sistem informasin akuntansi, hal ini di dukung dengan hasil penelitian dari Septianingrum (2014) yaitu adanya pengaruh positif dan 
signifikan dari pelatihan pemakai terhadap kinerja SIA. Dengan demikian hipotesis yang dapat dirumuskan sebagai berikut:

$\mathrm{H}_{3}$ : Pendidikan dan Pelatihan pemakai berpengaruh positif terhadap kinerja sistem informasi akuntansi

\section{METODE PENELITIAN}

Pendekatan yang digunakan dalam penelitian ini adalah pendekatan kuantitatif yang berbentuk asosiatif. Seperti rumusan masalah dalam penelitian ini yaitu variabel Pelatihan dan Pendidikan (X3) sebagai pengaruh Variabel Keterlibatan Pemakai (X2) dan Variabel Teknik Personal (X1) terhadap Sistem Informasi Akuntansi (Y).

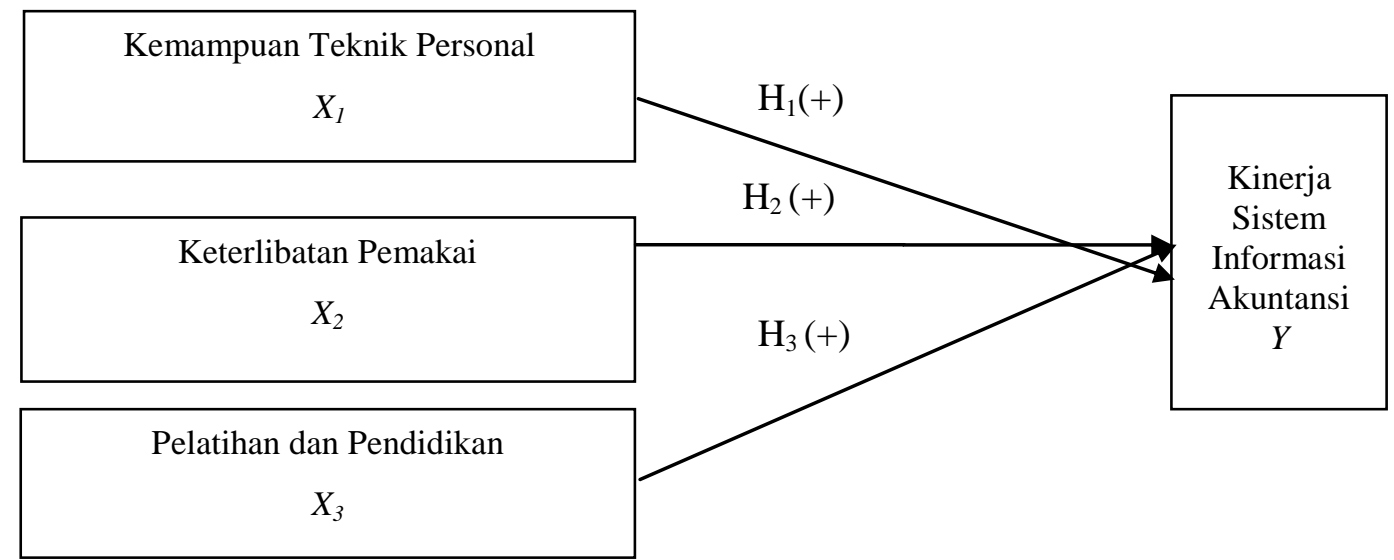

Sumber :

\section{Gambar 1. DesainPenelitian}

$\mathrm{H}_{1}$ : Almilia dan Briliantien (2006), Adventri (2008), Wirayanti dkk. (2015)

$\mathrm{H}_{2}$ : Komara (2006), Damana dan Suardikha (2016), Tjhai (2002)

$\mathrm{H}_{3}$ : Tjhai (2002), Forthe dan Soegiharto (2001), Septianingrum (2014)

Lokasi penelitian dilakukan pada Lembaga Perkreditan Desa (LPD) Kota Denpasar. Hal ini disebabkan karena Kota Denpasar menjadi pusat kegiatan bisnis, dan merupakan daerah yang memiliki pendapatan per kapita dan 
pertumbuhan tinggi di Provinsi Bali, sehingga penting adanya peran LPD dalam upaya menunjang modal usaha yang diperlukan masyarakat, untuk itu diperlukan sistem informasi akuntansi yang baik dalam meningkatkan kinerja LPD sehingga dapat bersaing dengan lembaga keuangan lainnya. Sedangkan obyek dalam penelitian ini adalah teknik personal, keterlibatan pemakai, pelatihan dan pendidikan, sistem informasi akuntansi.

Variabel terikat dalam penelitian ini adalah kinerja Sistem Informasi Akuntansi (Y). Sedangkan variabel bebas dalam penelitian ini adalah Teknik Personal $\left(\mathrm{X}_{1}\right)$, Keterlibatan Pemakai $\left(\mathrm{X}_{2}\right)$, Pelatihan dan Pendidikan $\left(\mathrm{X}_{3}\right)$. Jenis data yang digunakan dalam penelitian ini adalah data kuantitatif berupa hasil jawaban responden yang telah diberi skor dengan bantuan sekala likert pada Lembaga Perkreditan Desa di Kota Denpasar. Data Kualitatif yang digunakan dalam penelitian ini berupa daftar nama Lembaga Perkreditan Desa di Kota Denpasar. Sedangkan sumber data yang digunakan dalam penelitian ini adalah data primer berupa jawaban responden terhadap pernyataan kuesioner yang dikumpulkan dari Lembaga Perkreditan Desa di Kota Denpasar. Data sekunder dalam penelitian ini berupa data mengenai daftar LPD di Kota Denpasar.

Populasi dalam penelitian ini adalah seluruh pegawai LPD yang berada di Kota Denpasar. Berdasarkan data yang diperoleh dari Lembaga Pemberdayaan Lembaga Perkreditan Desa (LP-LPD) jumlah LPD yang berada di Kota Denpasaradalah 35 LPD dengan jumlah pegawai sebanyak 525 pegawai, LPD yang kurang sehat tidak masuk kriteria yaitu 2 LPD. Sehingga yang ditentukan sebanyak 33 LPD yang sudah menggunakan SIA sesuai dengan kriteria. 
Sampel yang diambil menggunakan teknik purposive sampling yaitu metode penentuan sampel dengan pertimbangan tertentu dimana anggota-anggota sampel akan dipilih sedemikian rupa sehingga dapat mewakili sifat-sifat populasi (Sugiyono, 2013). Berdasarkan kriteria yang ditentukan maka responden dalam penelitian ini kemudian dipilih 3 orang pada masing-masing LPD di Kota Denpasar. Oleh karena itu jumlah sampel dalam penelitian ini adalah sebanyak 99 orang pegawai LPD. Pengumpulan data dalam penelitian ini menggunakan teknik wawancara yang dilakukan dengan pimpinan dan pegawai Lembaga Perkreditan Desa yang terlibat langsung dengan sistem informasi akuntansi. Sedangkan kuesioner dalam penelitian ini disebarkan langsung LPD di kota Denpasar dan ditujukan kepada kepala atau tata usaha pada LPD di Kota Denpasar.

Teknik analisis data yang digunakan dalam penelitian ini adalah teknik analisis regresi linier berganda. Sebelum melakukan pengujian regresi, terdapat beberapa asumsi yang harus dipenuhi agar data yang akan dimasukkan dalam model regresi telah memenuhi ketentuan dan syarat dalam regresi. Uji asumsi klasik dalam penelitian ini mencakup uji normalitas, multikolinearitas, dan heteroskedastisitas. Model regresi linier berganda dirumuskan sebagai berikut.

$$
\mathrm{Y}=\alpha+\beta_{1} \mathrm{x}_{1}+\beta_{2} \mathrm{X}_{2}+\beta_{3} \mathrm{x}_{3}+\mathrm{e}
$$

Keterangan :

Y : Kinerja Sistem Informasi Akuntansi

$\alpha$ : Konstanta

$\beta_{1}, \beta_{2}, \beta_{3}$ : Koefisien regresi variabel independen

$\mathrm{x}_{1}$ : Kemampuan Teknik Personal

$\mathrm{x}_{2}$ : Keterlibatan Pemakai

$\mathrm{x}_{3}$ : Pelatihan dan Pendidikan

e : Nilai residu 
Berdasarkan hasil analisis yang dilakukan dapat diamati mengenai koefisien determinasi $\left(\mathrm{R}^{2}\right)$, uji kelayakan model (uji F), dan uji hipotesis (uji t).

\section{HASIL DAN PEMBAHASAN}

Karakteristik responden meliputi jenis kelamin, umur, tingkat pendidikan dan lama kerja responden. Ringkasan mengenai karakteristik responden dapat dilihat pada Tabel 1. sebagai berikut:

Tabel 1.

Karakteristik Pegawai LPD di Kota Denpasar

\begin{tabular}{|c|c|c|c|c|}
\hline No & Karakteristik & Klasifikasi & $\begin{array}{l}\text { Jumlah } \\
\text { Responden } \\
\text { (orang) }\end{array}$ & $\begin{array}{c}\text { Persentase } \\
\text { Responden } \\
(\%)\end{array}$ \\
\hline \multirow{2}{*}{1} & \multirow{2}{*}{ Jenis Kelamin } & Laki-laki & 69 & 69,70 \\
\hline & & Perempuan & 30 & 30,30 \\
\hline \multirow{7}{*}{2} & \multirow[t]{2}{*}{ Jumlah } & & 99 & 100 \\
\hline & & 21 - 30 Tahun & 24 & 24,24 \\
\hline & \multirow{3}{*}{ Umur } & 31 - 40 Tahun & 39 & 39,39 \\
\hline & & $40-50$ Tahun & 26 & 26,26 \\
\hline & & $>50$ Tahun & 10 & 10,10 \\
\hline & \multirow[t]{2}{*}{ Jumlah } & & 99 & 100 \\
\hline & & SMA & 27 & 27,27 \\
\hline \multirow{3}{*}{3} & \multirow{3}{*}{$\begin{array}{c}\text { Jenjang Pendidikan } \\
\text { Terakhir }\end{array}$} & Diploma & 23 & 23,23 \\
\hline & & Sarjana & 41 & 41,41 \\
\hline & & Pascasarjana & 8 & 8,08 \\
\hline \multirow{5}{*}{4} & \multirow[t]{2}{*}{ Jumlah } & & 99 & 100 \\
\hline & & 1-5 tahun & 38 & 38,38 \\
\hline & \multirow[t]{2}{*}{ Lama Kerja } & 5-10 tahun & 51 & 51,52 \\
\hline & & $>10$ tahun & 10 & 10,10 \\
\hline & Jumlah & & 99 & 100 \\
\hline
\end{tabular}

Sumber: Data diolah, 2018

Tabel 1 menunjukkan responden dalam penelitian ini yaitu pegawai LPD di Kota Denpasar dominan berjenis kelamin laki-laki dengan jumlah sebanyak 69 orang atau sebesar 69,70 persen, sedangkan pegawai perempuan sebanyak 30 orang atau 30,30 persen. Artinya lebih banyak pegawai laki-laki dibandingkan perempuan yang bekerja pada LPD di Kota Denpasar. Dilihat dari segi usia, responden yang berusia 21-30 tahun sebanyak 24 orang atau sebesar 24,24 persen, 
responden yang berusia 31-40 tahun sebanyak 39 orang atau sebesar 39,39 persen, responden yang berusia 40-50 tahun sebanyak 26 orang atau 26,26 persen, dan responden yang berusia lebih dari 50 tahun sebanyak 10 orang atau sebesar 10,10 persen. Hal ini menunjukkan bahwa pegawai yang bekerja di LPD di Kota Denpasar mayoritas adalah yang berusia 31-40 tahun.

Tabel 1 menunjukkan mayoritaspegawai LPD di Kota Denpasar adalah kelompok responden dengan tingkat pendidikan Sarjana dengan jumlah sebanyak 41 orang atau 41,41 persen, kemudian responden dengan tingkat pendidikan SMA sebanyak 27 orang atau 27,27 persen, responden dengan tingkat pendidikan Diploma sebanyak 23 orang atau 23,23 persen dan Pascasarjana sebanyak 8 orang atau 8,08 persen. Informasi ini memberikan gambaran bahwa pegawai LPD di Kota Denpasar paling dominan adalah lulusan Sarjana yang dianggap sudah mampu serta memadai untuk menjadi pegawai LPD yang memiliki kompetensi untuk mencapai tujuan organisasi.

Pengelompokkan responden berdasarkan masa kerja menunjukkan bahwa responden yang bekerja pada LPD di Kota Denpasar dengan masa kerja selama 1 sampai 5 tahun adalah sebanyak 38 orang atau 38,38 persen, kemudian responden yang bekerja selama 5 sampai 10 tahun sebanyak 51 orang atau 51,52 persen, sedangkan yang bekerja lebih dari 10 tahun sebanyak 10 orang atau 10,10 persen. Hal ini mengindikasikan bahwa sebagian besar pegawai LPD di Kota Denpasar memiliki masa kerja 5 sampai 10 tahun.

Suatu instrumen dikatakan valid apabila memiliki koefisien korelasi antara butir dengan skor total dalam instrumen tersebut lebih besar dari 0,30 dengan 
tingkat kesalahan Alpha 0,05. Hasil rekapitulasi uji validitas dalam penelitian ini disajikan dalam Tabel 2. sebagai berikut:

Tabel 2.

Rekapitulasi Hasil Uji Validitas Instrumen Penelitian

\begin{tabular}{ccccc}
\hline Variabel & Indikator & Koefisien Korelasi & Sig. (2-tailed) & Keterangan \\
\hline Kemampuan teknik & $\mathrm{X}_{1.1}$ & 0,790 & 0,000 & Valid \\
personal & $\mathrm{X}_{1.2}$ & 0,831 & 0,000 & Valid \\
$\left(\mathrm{X}_{1}\right)$ & $\mathrm{X}_{1.3}$ & 0,820 & 0,000 & Valid \\
& $\mathrm{X}_{2.1}$ & 0,696 & 0,000 & Valid \\
Keterlibatan & $\mathrm{X}_{2.2}$ & 0,755 & 0,000 & Valid \\
pemakai & $\mathrm{X}_{2.3}$ & 0,679 & 0,000 & Valid \\
$\left(\mathrm{X}_{2}\right)$ & $\mathrm{X}_{2.4}$ & 0,694 & 0,000 & Valid \\
& $\mathrm{X}_{2.5}$ & 0,420 & 0,000 & Valid \\
& $\mathrm{X}_{3.1}$ & 0,751 & 0,000 & Valid \\
Pelatihan dan & $\mathrm{X}_{3.2}$ & 0,654 & 0,000 & Valid \\
pendidikan & $\mathrm{X}_{3.3}$ & 0,685 & 0,000 & Valid \\
$\left(\mathrm{X}_{3}\right)$ & $\mathrm{X}_{3.4}$ & 0,652 & 0,000 & Valid \\
& $\mathrm{X}_{3.5}$ & 0,593 & 0,000 & Valid \\
& $\mathrm{Y}_{1}$ & 0,512 & 0,000 & Valid \\
& $\mathrm{Y}_{2}$ & 0,584 & 0,000 & Valid \\
& $\mathrm{Y}_{3}$ & 0,736 & 0,000 & Valid \\
Kinerja sistem & $\mathrm{Y}_{4}$ & 0,627 & 0,000 & Valid \\
akuntansi(Y) & $\mathrm{Y}_{5}$ & 0,640 & 0,000 & Valid \\
& $\mathrm{Y}_{6}$ & 0,317 & 0,031 & Valid \\
& $\mathrm{Y}_{7}$ & 0,643 & 0,000 & Valid \\
\hline Sumid & & & &
\end{tabular}

Sumber: Data diolah, 2018

Hasil uji validitas pada tabel 2. menunjukkan bahwa seluruh instrumen penelitian yang digunakan untuk mengukur variabel kemampuan teknik personal, keterlibatan pemakai, pelatihan dan pendidikan, serta kinerja sistem informasi akuntansi memiliki nilai koefisien korelasi dengan skor total seluruh item pernyataan lebih besar dari 0,30 dengan signifikansi kurang dari 0,05 . Hal ini menunjukkan bahwa butir-butir pernyataan dalam instrument penelitian tersebut valid dan layak digunakan sebagai instrument penelitian.

Uji Reliabilitas terhadap instrumen penelitian ini menggunakan nilai Cronbach's Alpha. Nilai Alpha Cronbach dinyatakan reliabel jika nilainya lebih 
besar atau sama dengan 0,60. Rekapitulasi hasil uji reliabilitas instrumen penelitian dapat dilihat pada Tabel 3 .

Tabel 3.

Rekapitulasi Hasil Uji Reliabilitas Instrumen Penelitian

\begin{tabular}{clll}
\hline No. & \multicolumn{1}{c}{ Variabel } & $\begin{array}{c}\text { Cronbach's } \\
\text { Alpha }\end{array}$ & Keterangan \\
\hline 1 & Kemampuan teknik personal $\left(\mathrm{X}_{1}\right)$ & 0,831 & \\
2 & Keterlibatan pemakai $\left(\mathrm{X}_{2}\right)$ & 0,747 & Reliabel \\
3 & Pelatihan dan pendidikan $\left(\mathrm{X}_{3}\right)$ & 0,765 & Reliabel \\
4 & Kinerja sistem informasi akuntansi $(\mathrm{Y})$ & 0,722 & Reliabel \\
\hline
\end{tabular}

Sumber: Data diolah, 2018

Hasil uji reliabilitas yang disajikan dalam Tabel 3. menunjukkan bahwa seluruh instrumen penelitian memiliki koefisien Cronbach's Alpha lebih dari 0,60. Jadi dapat dinyatakan bahwa seluruh variabel telah memenuhi syarat reliabilitas atau kehandalan sehingga dapat digunakan melakukan penelitian.

Uji normalitas menggunakan uji Kolmogorov-Smirnov, dengan uji ini dapat diketahui data yang digunakan berdistribusi normal atau tidak. Apabila Sign $\mathrm{t}$ hitung $>0.05$, maka data tersebut berdistribusi normal dan begitu juga sebaliknya (Santoso, 2001). Berdasarkan hasil analisis didapat nilai signifikansi sebesar 0,752 seperti yang ditunjukkan oleh Tabel 4. Oleh karena nilai signifikansi uji Kolmogorov-Smirnov lebih dari 0,05 maka dapat disimpulkan bahwa model persamaan regresi tersebut berdistribusi normal.

Tabel 4.

Hasil Uji Normalitas

\begin{tabular}{cc}
\hline & Unstandardized Residual \\
\hline N & 99 \\
Kolmogorov-Smirnov Z & 0,675 \\
Asymp.Sig.(2-tailed) & 0,752 \\
\hline Sumber: Data diolah, 2018
\end{tabular}


Uji multikolinieritas digunakan untuk mengetahui apakah antara variabel bebas terjadi multikolinieritas atau tidak. Uji yang digunakan yaitu dengan melihat nilai VIF (Varian Inflation Factor) dan Tolerance pada proses regresi biasa, jika keduanya mendekati 1 atau besaran VIF kurang dari 10 maka model tidak terkena multikolinieritas. Berdasasrkan hasil pengujian multikolinearitas dapat diperoleh hasil sebagai berikut.

Tabel 5. Hasil Uji Multikoleniaritas

\begin{tabular}{lccc}
\hline \multicolumn{1}{c}{ Variabel } & Tolerance & VIF & Keterangan \\
\hline Kemampuan teknik personal $\left(\mathrm{X}_{1}\right)$ & 0,682 & 1,466 & Bebas multikol \\
Keterlibatan pemakai $\left(\mathrm{X}_{2}\right)$ & 0,714 & 1,400 & Bebas multikol \\
Pelatihan dan pendidikan $\left(\mathrm{X}_{3}\right)$ & 0,531 & 1,885 & Bebas multikol \\
\hline
\end{tabular}
Sumber: Data diolah, 2018

Berdasarkan Tabel 5. dapat dilihat bahwa nilai tolerance dan VIF dari seluruh variable tersebut menunjukkan bahwa nilai tolerance untuk setiap variabel lebih besar dari $10 \%$ dan nilai VIF lebih kecil dari 10 yang berarti model persamaan regresi bebas dari multikolinearitas.

Uji Heterokedastisitas dilakukan untuk menguji apakah dalam model regresi terjadi ketidaksamaan varian dari residu satu pengamatan ke pengamatan lain. Model regresi yang baik adalah model homokedastisitas atau tidak terjadi heterokedastisitas. Apabila model suatu regresi mengandung gejala heterokedastisitas, maka hasil yang diberikan akan menyimpang. Untuk mengetahui apakah sebuah regresi memiliki indikasi heterokedastisitas, maka masalah tersebut bisa dideteksi dengan menggunakan uji Glejser Test. Jika probabilitas signifikansinya di atas 0,05 maka dapat dikatakan bahwa pada model 
regresi tidak mengandung masalah heterokedastisitas . Hasil uji heterokedastisitas dapat dilihat pada Tabel 6 .

Tabel 6.

Hasil Uji Heteroskedastisitas

\begin{tabular}{clcc}
\hline No & \multicolumn{1}{c}{ Variabel Bebas } & Signifikansi & Keterangan \\
\hline 1 & Kemampuan teknik personal $\left(\mathrm{X}_{1}\right)$ & 0,161 & Bebas heteros \\
2 & Keterlibatan pemakai $\left(\mathrm{X}_{2}\right)$ & 0,065 & Bebas heteros \\
3 & Pelatihan dan pendidikan $\left(\mathrm{X}_{3}\right)$ & 0,375 & Bebas heteros \\
\hline
\end{tabular}

Sumber: Data diolah, 2018

Pada Tabel 6. dapat dilihat bahwa nilai Signifikansi dari variabel kemampuan teknik personal sebesar 0,161, keterlibatan pemakai sebesar 0,065, serta pelatihan dan pendidikan sebesar 0,375. Nilai tersebut lebih besar dari 0,05 yang berarti tidak terdapat pengaruh antara variabel bebas terhadap absolute residual. Dengan demikian, model yang dibuat tidak mengandung gejala heteroskedastisitas.

Setelah semua asumsi klasik terpenuhi, maka selanjutnya memaparkan hasil analisis regresi linier berganda. Berdasarkan hasil analisis regresi linier berganda seperti yang disajikan pada Tabel 7. maka dapat dibuat persamaan regresi sebagai berikut:

$$
Y=7,673+0,323 X_{1}+0,502 X_{2}+0,237 X_{3}
$$

Tabel 7.

Hasil Analisis Regresi Linier Berganda

\begin{tabular}{|c|c|c|c|c|c|}
\hline \multirow[t]{2}{*}{ Model } & \multicolumn{2}{|c|}{$\begin{array}{c}\text { Unstandardized } \\
\text { Coefficients }\end{array}$} & \multirow{2}{*}{$\begin{array}{c}\text { Standardized } \\
\text { Coefficients } \\
\text { Beta }\end{array}$} & \multirow[b]{2}{*}{$\mathrm{T}$} & \multirow[b]{2}{*}{ Sig. } \\
\hline & $\mathrm{B}$ & Std. Error & & & \\
\hline (Constant) & 7,673 & 1,442 & & 5,320 & 0,000 \\
\hline Kemampuan Teknik Personal & 0,323 & 0,126 & 0,221 & 2,567 & 0,012 \\
\hline Keterlibatan Pemakai & 0,502 & 0,094 & 0,451 & 5,367 & 0,000 \\
\hline Pelatihan dan Pendidikan & 0,237 & 0,104 & 0,222 & 2,278 & 0,025 \\
\hline
\end{tabular}


Nilai koefisien regresi masing-masing variabel bebas bernilai positif dengan nilai signifikansi uji t kurang dari 0,05. Hal ini menunjukkan bahwa semua variabel bebas memiliki pengaruh positif yang signifikan terhadap variabel terikat.

Tabel 8.

HasilUji Koefisien Determinasi $\left(\mathbf{R}^{\mathbf{2}}\right)$

\begin{tabular}{rcccc}
\hline Model & $\mathrm{R}$ & $\mathrm{R}$ Square & Adjusted R Square & Std. Error of the Estimate \\
\hline 1 & $0,722^{\mathrm{a}}$ & 0,521 & 0,506 & 1,809 \\
\hline
\end{tabular}

Sumber: Data diolah, 2018

Hasil uji pada Tabel 8. memberikan hasil dimana diperoleh besarnya adjusted $\mathrm{R}^{2}$ (koefisien determinasi yang telah disesuaikan) adalah sebesar 0,506. Ini berarti variasi kinerja sistem informasi akuntansi pada LPD di Kota Denpasar dapat dipengaruhi secara signifikan oleh variabel kemampuan teknik personal, keterlibatan pemakai, serta pelatihan dan pendidikan, sebesar 50,6 persen, sedangkan sisanya sebesar 49,4 persen dijelaskan oleh faktor-faktor lain yang tidak dijelaskan dalam model penelitian.

Tabel 9.

\section{Hasil Uji F}

\begin{tabular}{lllllll}
\hline Model & & Sum of Squares & Df & Mean Square & $F$ & Sig. \\
\hline & Regression & 328,283 & 4 & 82,071 & 48,746 & $000^{\mathrm{a}}$ \\
& Residual & 158,262 & 94 & 1,684 & & \\
& Total & 486,545 & 98 & & & \\
\hline
\end{tabular}

Sumber: Data diolah, 2018

Hasil uji F (Ftest) pada Tabel 9. menunjukkan bahwa nilai signifikansi $\mathrm{P}$ value 0,000 yang lebih kecil dari $\alpha=0,05$, ini berarti model yang digunakan pada penelitian ini adalah layak. Hasil ini memberikan makna bahwa seluruh variabel independen mampu memprediksi atau menjelaskan fenomena kinerja sistem informasi akuntansi pada LPD di Kota Denpasar. Hal ini berarti model dapat digunakan untuk analisa lebih lanjut atau dengan kata lain model dapat digunakan 
untuk memproyeksikan karena hasil goodness of fitnya baik dengan nilai signifikansi $\mathrm{P}$ value 0,000 .

Berdasarkan hasil analisis pengaruh kemampuan teknik personal terhadap kinerja sistem informasi akuntansi pada Tabel 7. diperoleh nilai signifikasi sebesar 0,012 dengan nilai koefisien beta 0,323. Nilai signifikansi $0,012<0,05$ mengindikasikan bahwa $\mathrm{H}_{0}$ ditolak dan $\mathrm{H}_{1}$ diterima. Hasil ini mempunyai arti bahwa kemampuan teknik personal berpengaruh positif dan signifikan terhadap kinerja sistem informasi akuntansi pada LPD di Kota Denpasar.

Keberhasilan suatu pengembangan sistem informasi tidak hanya ditentukan oleh kecanggihan sistem tersebut tetapi ditentukan oleh kesesuaiannya dengan para pemaki sistem tersebut (Kusumastuti dan Irwandi, 2012). Semakin rendah tingkat kemampuan teknik personal maka tingkat kinerja sistem informasi akuntansi yang dihasilkan akan semakin rendah, begitu pula sebaliknya.

Penelitian ini sesuai dengan temuan Arrahman (2016) yang menemukan bahwa kemampuan teknik personal sistem informasi merupakan pengaruh utama dari perekrutan pegawai dan perancangan sistem informasi akuntansi. Hasil penelitian ini didukung beberapa hasil penelitian sebelumnya dan konsisten dengan hasil penelitian yang dilakukan oleh Almilia and Briliantien (2007), Adventri (2008), dan Wirayanti dkk. (2015) memperoleh kesimpulan bahwa kemampuan teknik personal akuntansi barpengaruh positif signifikan terhadap kinerja sistem informasi akuntansi.

Berdasarkan hasil analisis pengaruh keterlibatan pemakai terhadap kinerja sistem informasi akuntansi pada Tabel 7. diperoleh nilai signifikansi sebesar 0,000 
dengan nilai koefisien beta 0,502 . Nilai signifikansi $0,000<0,05$ mengindikasikan bahwa $\mathrm{H}_{0}$ ditolak dan $\mathrm{H}_{2}$ diterima. Hasil ini mempunyai arti bahwa keterlibatan pemakai berpengaruh positif dan signifikan terhadap kinerja sistem informasi akuntansi pada LPD di Kota Denpasar.

Keterlibatan pemakai adalah keterlibatan mental dan emosional orang-orang dalam situasi kelompok yang mendorong mereka untuk memberikan kontribusi kepada tujuan kelompok (Damana dan Suardikha, 2016). Semakin tinggi tingkat keterlibatan pemakai maka tingkat kinerja sistem informasi akuntansi yang dihasilkan akan semakin tinggi, begitu pula sebaliknya.

Penelitian ini sesuai dengan temuan Tjhai (2002) yang menyatakan bahwa keterlibatan pemakai yang semakin sering akan meningkatkan kinerja SIA. Hasil penelitian ini juga didukung oleh beberapa hasil penelitian sebelumnya dan konsisten dengan hasil penelitian Hajiha dan Azizi (2011), Alanita dan Suaryana (2014), Damana dan Suardikha (2016), dan Komara (2006) yang memperoleh hasil bahwa keterlibatan pemakai berpengaruh positif dan signifikan.

Berdasarkan hasil analisis pengaruh pelatihan dan pendidikan terhadap kinerja sistem informasi akuntansi pada Tabel 7. diperoleh nilai signifikansi sebesar 0,025 dengan nilai koefisien beta 0,237. Nilai signifikansi $0,025<0,05$ mengindikasikan bahwa $\mathrm{H}_{0}$ ditolak dan $\mathrm{H}_{3}$ diterima. Hasil ini mempunyai arti bahwa pelatihan dan pendidikan berpengaruh positif dan signifikan terhadap kinerja sistem informasi akuntansi pada LPD di Kota Denpasar.

Pelatihan dan pendidikan pemakai bertujuan untuk meningkatkan kesadaran akan informasi dan keterampilan dalam pengambilan keputusan. Pelatihan 
berkaitan dengan keahlian dan kemampuan untuk melaksanakan pekerjaannya (Tian-Hui, 2009). Semakin tinggi tingkat pelatihan dan pendidikan yang dimiliki pegawai maka tingkat kinerja sistem informasi akuntansi yang dihasilkan akan semakin tinggi.

Hasil penelitian ini sesuai dan konsisten dengan hasil penelitian Soegiharto (2001) yang menyatakan bahwa pendidikan pemakai sangat mempengaruhi kinerja sistem informasin akuntansi. Hasil penelitian ini juga didukung oleh penelitian Septianingrum (2014), Rivai (2004) dan Tian-Hui (2009) yang mengatakan bahwa pelatihan dan pendidikan berpengaruh positif signifikan terhadap kinerja sistem informasi akuntansi.

\section{SIMPULAN}

Berdasarkan pembahasan hasil penelitian, dapat disimpulkan bahwa kemampuan teknik personal, keterlibatan pemakai, dan pelatihan dan pendidikan berpengaruh positif dan signifikan terhadap Kinerja sistem informasi akuntansi pada LPD di Kota Denpasar. Sedangkan saran yang dapat diberikan yaitu Lembaga LPD diharapkan dengan memberikan pendidikan dan pelatihan secara berkala kepada pegawai LPD, agar pegawai mampu beradaptasi terhadap hal-hal baru khususnya mengenai sistem informasi akuntansi sehingga dapat meningkatkan kinerja pegawai tersebut. Selain itu sebaiknya LPD di Kota Denpasar lebih memperhatikan faktor-faktor yang dapat mempengaruhi kinerja sistem informasi akuntansi LPD tersebut dalam upaya meningkatkan kinerja sistem informasi akuntansi. Selain itu hasil dari penelitian ini diharapkan mampu mendorong 
peneliti-peneliti selanjutnya untuk mengamati faktor-faktor lain yang dapat mempengaruhi kinerja sistem informasi akuntansi.

\section{REFERENSI}

Adventri, B. (2008). Analisis Faktor-Faktor Yang Mempengaruhi Kinerja Sistem Informasi Akuntansi (Survei Terhadap Tiga Badan Usaha Milik Negara di Bandung. Skripsi Fakultas Ekonomi Universitas Widyatama.

Al-eqab, M., \& Adel, D. (2013). The Impact of IT Sophistications on the Perceived Usefulness of Accounting Information Characteristics among Jordanian Listed Companies. Journal of Bussiness and Social Science, 4(3), $145-155$.

Alanita, N. P., \& Suaryana, I. G. N. A. (2014). Pengaruh Kecanggihan Teknologi Informasi, Partisipasi Manajemen, dan Kemampuan Teknik Pemakai Sistem Informasi Akuntansi pada Kinerja Individu. E-Jurnal Akuntansi Universitas Udayana, 6(1), 33-45.

Almilia, L. S., \& Briliantien, I. (2007). Faktor-faktor Yang Mempengaruhi Kinerja Sistem Informasi Akuntansi pada Bank Umum Pemerintah di Wilayah Surabaya dan Sidoarjo. Jurnal STIE Perbanas Surabaya, 1-7.

Aplonia, E. L. (2004). Pengaruh Partisipasi Pemakai Terhadap Kepuasan Pemakai Dalam Pengembangan Sistem Informasi dengan Lima Variabel Moderating. Jurnal Riset Akuntansi Indonesia, 7(1).

Ayu, P. (2012). Analisis Faktor -Faktor yang Mempengaruhi Kinerja Sistem Informasi Akuntansi Pada Lembaga Perkreditan Desa Di Kecamatan Denpasar Utara. Skripsi Fakultas Ekonomi Universitas Udayana.

Baig, A. H. and Gururajan, R. (2011). Preliminary Study to Investigation the Determinants that Effect IS/IT Outsourcing. Journal of Information and Communication Technology Research, 1(2), 48-54.

Beke, J. (2010). Review of International Accounting Information System. Journal Of Accounting and Taxation, 2(2), 025-030.

Choe, J. M. (1996). The Relationship Among Performance Of Accounting Information Sytem, Influence Factors, And Evolution Level Of Information System. Journal Of Management Information System, 12(4), 215-239. 
Damana, A. W. A., \& Suardikha, I. M. S. (2016). Pengaruh Keterlibatan Pemakai, Pelatihan, Ukuran Organisasi dan Keahlian Pemakai Terhadap Kinerja Sistem Informasi Akuntansi. E-Jurnal Akuntansi Universitas Udayana, 14(2), 1452-1480.

Davis, F. D. (1989). Perceived Usefulness, Perceived Ease Of Use, and User Acceptance Of Information Technology. MIS Quarterly, 13(5), 319-339.

Edi., E. A., \& Wahyuningrum. (2017). Manfaat Sistem Informasi Akuntansi Untuk Efektivitas Keuangan, Manajemen, dan Organisasi. Jurnal Benefita, 2(2), 110-121.

Fani, L. N. Y., Surya, D. N. A., \& Purnamawati, I. G. A. (2015). Pengaruh Kecanggihan Teknologi Informasi, Kemampuan Teknik Pemakai, dan Dukungan Manajemen Puncak Terhadap Kinerja Sistem Informasi Akuntansi Studi Empiris pada PT PLN (Persero) Area Bali Utara (Kantor Pusat). E-Journal Universitas Pendidikan Ganesha, 3(1), 1-12.

Gunawan, I. M. P., \& Indra, T. A. (2017). Pengaruh Efektivitas Sistem Informasi Akuntansi Pada Kinerja Individual Dengan Kemampuan Teknik Personal Sebagai Pemoderasi. E-Jurnal Akuntansi Universitas Udayana, 20(2), 16211647.

Hajiha, Z., \& Azizi, Z. A. P. (2011). Effective Factors on Alignment of Accounting Information Systems in Manufacturing Companies: Evidence from Iran. Journal Information Management and Business Review, 3(3), $158-170$.

Kharisma, M. D. dan Dharmadiaksa, I. B. (2015). Pengaruh Keterlibatan Pengguna dan Ukuran Organisasi terhadap Efektivitas Penggunaan Sistem Informasi Akuntansi Dengan Kapabilitas Personal Sistem Informasi Sebagai Variabel Pemoderasi Di PT Bank Sinar Harapan Bali denpasar. EJurnal Akuntansi Universitas Udayana, 10(3), 867-881.

Komara, A. (2006). Analisis Faktor-Faktor yang Mepengaruhi Kinerja Sistem Informasi Akuntansi. Jurnal Manajemen, Akuntansi, Dan Sistem Informasi, 6(2), 143-160.

Kusumastuti, M. C., \& Irwandi, S. A. (2012). Investigasi Empat Faktor Kontigensi Sebagai Variabel Moderating Terhadap Partisipasi Pemakai dan Kepuasan Pemakai Dalam Pengembangan Sistem Informasi. Jurnal AkuntansiFakultas Ekonomi STIE Parbanas, 2(2), 139-150.

Laudon, K. C., \& Laudon, J. P. (2008). Sistem Informasi Manajemen Terjemahan Chriswan Sungkono dan Machmudin Eka P (10th ed.). Jakarta: Salemba Empat. 
Marija, T. S., Mateo, T. I., \& Blazevic, I. (2011). Functional Structure of Entrepreneurial Accounting Information Systems. International Journal Of Engineering, 9(2).

Nurhayanti, Y. (2012). Analisis Faktor-Faktor Yang Mempengaruhi Kinerja Sistem Informasi Akuntansi Pada Minimarket di Wilayah Jakarta. Jurnal Akuntansi Universitas Gunadarma, 18(12), 1-12.

Nithyanandam, K. E. Kanniyapan, M. A. D., \& Rajasekar, V. (2006). User Education Programmes And Academic Libraries. International Convention Caliber.

Onaolapo, A. A. and Odetayo, T. A. (2012). Effect of Accounting Information System on Organi sational Effectiveness. American Journal of Business and Management, 1(4), 183-189.

Putri, N. W. I. D., \& Dharmadiaksa, I. B. (2015). Pengaruh Kemampuan Teknik Personal, Program Pelatihan Dan Pendidikan, Insentif, Dan Partisipasi Manajemen Pada Kinerja Penerapan SIA. E-Jurnal Akuntansi Universitas Udayana, 12(3), 582-592.

Restuningdiah, N dan Indriantoro, N. (2000). Pengaruh Partisipasi terhadap kepuasan pengguna dalam pengembangan system informasi dengan kompleksitas tugas, kompleksitas sistem dan pengaruh pengguna sebagai moderating variable. Jurnal Analisis Bisnis dan Ekonomi, 2(2), 105-123.

Rivai, V. (2004). Manajemen Sumber Daya Manusia Untuk Perusahaan. Jakarta: PT Raja Grafindo Persada.

Robbins, S. P. (2008). Organizational Behavior (11th ed.). New jersey: Pearson Education inc.

Rose, J., \& Gerard, F. (2006). Determinants of perceived usefulness and perceived ease of use in The Technology Acceptance Model: Senior Consumers Adoption of Self-Serving Banking Technologies. Academy of World Business, Marketing \& Management Development Conference Proceedings, 2(10), 122-129.

Rouibah, K., Hamdy, H. I., \& Al-Enezi, M. Z. (2009). Effect of management support, training and user involvement in system usage and satisfaction in Kuwait. Ind Manage Data Syst, 103, 338-356.

Septi, R. M. (2017). Pengaruh Kecanggihan Teknologi Informasi, Partisipasi Pengguna, dan Kemampuan Pengguna Terhadap Kinerja Sistem Informasi Akuntansi Pada PT PLN (Persero) Area Bali Utara (Kantor Pusat). Jurnal Akuntansi Universitas Pendidikan Ganesha, 7. 
Septianingrum, P. A. (2014). Pengaruh Dukungan Top Management, Kemampuan Pengguna serta Adanya Pelatihan dan Pendidikan Pengguna terhadap Kinerja Sistem Informasi Akuntansi. Skripsi Fakultas Ekonomi Universitas Negeri Yogyakarta.

Soegiharto. (2001). Influence Factors Affecting the Performance of Accounting Information System. Gajah Mada International Journal of Business, 3(2), 177-202.

Suartika, K. A., \& Sari, W. N. L. (2017). Kemampuan Teknik Personal Pada Efektivitas Penggunaan Sistem Informasi Akuntansi Dengan Pendidikan Dan Pelatihan Sebagai Pemoderasi. E-Jurnal Akuntansi Universitas Udayana, 18(2), 1485-1512.

Sugiyono. (2013). Metode Penelitian Bisnis. Bandung: Alfabeta.

Surendran, P. (2012). Technology Acceptance Model: A Survey of Literature. International Journal of Business and Social Research, 2(4).

Swandewi, L. P., Ariyanto, D., \& Dewi, L. G. K. (2017). Kepuasan Pengguna Sistem Informasi Akuntansi Pada Lembaga Perkreditan Desa di Kabupaten Buleleng. E-Jurnal Akuntansi Universitas Udayana, 19(3), 1803-1831.

Tian-Hui, Z. (2009). Libray User Education Under The Circumstance Of Network. Us-China Education Review, 6(12).

Tjhai, F. J. (2002). Faktor-faktor yang Mempengaruhi Kinerja Sistem Informasi Akuntansi. Jurnal Bisnis Dan Akuntansi, 4(2), 135-154.

Urquia, G. E. (2011). The Impact of Accointing Information System (AIS) on Performance measures: Empirical evidence in Spanish SMEs1. Journal International of Digital Accounting Research, 11(2), 25-43.

Utama, B. I. D. G. (2014). Faktor-Faktor yang Mempengaruhi Kinerja Sistem Informasi Akuntansi Pada Lembaga Perkreditan Desa. Skripsi Universitas Udayana.

Wibowo. (2007). Manajemen Kinerja. Jakarta: PT. Raja Grafindo Persada.

Wirayanti, P. M., Werastuti, D. N. S., \& Sujana, E. (2015). Pengaruh Partisipasi Pemakai Sistem Informasi, Kemampuan Pemakai Sistem Informasi, Ukuran Organisasi, Program Pelatihan Dan Pendidikan Terhadap Kinerja Sistem Informasi Akuntansi Dengan Kompleksitas Tugas Sebagai Variabel Moderating (Studi Empiris Pada PT. E-Journal Universitas Pendidikan Ganesha, 3(1), 1-11. 
I Gusti Ngurah Putu Ardiwinata dan I Ketut Sujana. Pengaruh ...

Xu, H., \& Dandong, L. (2003). The Critical Success Factors For Data Quality In Accounting Information System Different Industries' perspective. IACIS. 